\title{
$\begin{array}{llllll}S & \mathrm{~T} & \mathrm{U} & \mathrm{D} & \mathrm{I} & \mathrm{A}\end{array}$
}

\section{Laima Bucevičiūtè}

Uniwersytet Witolda Wielkiego w Kownie

\section{Regionalna specyfika pojęcia granic i pograniczy Wielkiego Księstwa Litewskiego w XV-XVI wieku}

\begin{abstract}
Zarys treści
Celem niniejszego artykułu jest ukazanie specyfiki pojęcia granic i pograniczy Litwy oraz jej sąsiadów w XV-XVI w. Przedstawiono etapy rozwoju granic państwa litewskiego i rozważono przypadek zmiany granicy Litwy w kontekście teoretycznym. Państwa posiadające wspólną granicę z Wielkim Księstwem Litewskim z punktu widzenia kultury regionu proponowały oraz konstruowały różne modele sąsiedztwa. Granica linearna ostatecznie sformowała się po zrealizowaniu programu wojskowo-obronnego, społeczno-ekonomicznego i kulturalno-ideowego opanowania terytorium. Tylko w przypadku północnych i zachodnich sąsiadów Litwie udało się stworzyć linearny model granicy. Za najważniejszy warunek do ukształtowania się granicy linearnej uważa się zjawisko kolonizacji wewnętrznej.
\end{abstract}

\begin{abstract}
The aim of this article is to present the concept and specificity of the borders and borderlands of Lithuania and its neighbours in the fifteenth and sixteenth centuries. The phases of the development of the Lithuanian state borders are presented and the case of Lithuanian border evolution is discussed in the context of the theory of border development. The states that bordered with the Grand Duchy of Lithuania offered and constructed a different neighbourhood model in terms of regional cultural approach. Linear state borders were finally formed after fulfilling the programme of military, socio-economic and cultural-ideological conquest of the area. The linear border model is applicable only to the northern and western borders of Lithuania. Internal colonization is regarded as the most important precondition for the creation of a linear border.
\end{abstract}

Słowa klucze: Wielkie Księstwo Litewskie, Polska, Liwonia, zakon krzyżacki, Prusy, Państwo Moskiewskie, ordy tatarskie, Imperium Osmańskie, granice, pogranicza, przestrzeń, terytorium, kolonizacja, stepy

Keywords: Grand Duchy of Lithuania, Poland, Livonia, Teutonic Order, Prussia, Muscovy, Tatar hordes, Ottoman Empire, boundaries, frontiers, space, territory, colonization, prairie 


\section{Wstęp}

Historia granic i terytorium Wielkiego Księstwa Litewskiego jest zagadnieniem szerokim. Z punktu widzenia struktury obszar Litwy dzielony jest na centrum i peryferia. Stosunki władzy pomiędzy centrum a peryferiami były specyficzne, kraj rozwijał się z różną intensywnością. Państwa mające wspólną granicę z Wielkim Księstwem Litewskim - Polska, Moskwa, Inflanty i państwo zakonu krzyżackiego w Prusach, Mołdawia, tatarska orda, a później Imperium Osmańskie - z punktu widzenia kultury regionu narzucały oraz konstruowały różne modele sąsiedztwa.

Terytorium i granice Litwy historycznej nie są tematem nowym w historiografii. Przeciwnie, poszczególne kwestie czy też grupy zagadnień dotyczących terytorium i granic państwa litewskiego stały się już obiektem zainteresowania badaczy. Zmiany obszaru państwa analizowane są w aspekcie historii politycznej i w perspektywie oceny wpływu działań wojennych, pewne zagadnienia granic ukazane są zaś w kontekście geografii historycznej, problemów lokalizacji granicy itd. Najczęściej historia granic Wielkiego Księstwa analizowana jest przez pryzmat stosunków politycznych, na pierwszy plan wysuwa się problematyka stosunków politycznych władzy centralnej, czyli wielkiego księcia, i należących do niego ziem. Stąd historiografia przedmiotu jest bardzo obszerna i zróżnicowana. Tutaj wymienię tylko najważniejsze pozycje, które wpłynęły na założenia badawcze niniejszej pracy. Najnowsze badania są autorstwa Tomasa Čelkisa ${ }^{1}$, który zaprezentował zupełnie nowy pogląd na pojęcie terytorium i granic państwa litewskiego. Również autorka niniejszego tekstu zaproponowała nowatorską koncepcję pojmowania kwestii terytorium i granic państwa litewskiego ${ }^{2}$. Konteksty oceny i analizy granic Litwy i Inflant oraz Litwy i państwa zakonu krzyżackiego,

\footnotetext{
${ }^{1}$ T. Čelkis, Nuo teritorinio ruožo prie linijos. Sienu sampratos pokyčiai Lietuvos Didžiojoje Kunigaikštystèje XIV-XVI amžiuje, „Lietuvos istorijos studijos” 22, 2008, s. 58-73; idem, Lietuvos Didžiosios Kunigaikštystès sienu sutartys ir delimitacijos procedūra XIV-XVI amžiuje, „Lietuvos istorijos studijos” 25, 2010, s. 25-47; idem, Lietuvos Didžiosios Kunigaikštystès teritorijos sienos „prie Juodosios jūros” XV-XVI a., „Istorija” 83, 2011, s. 3-13; idem, Lietuvos Didžiosios Kunigaikštystès sienu stepese XIV-XVI amžiuje samprata, „Lietuvos istorijos studijos” 30, 2012, s. 29-35; idem, Žemiu ribu ženklinimas Lietuvos Didžiojoje Kunigaikštystėje XV-XVI amžiuje, „Liaudies kultūra” 2013, nr 4, s. 16-26; T. Čelkis, D. Antanavičius, 1545 metu Livonijos ir Lietuvos Didžiosios Kunigaikštystès sienos patikrinimas (Livonijos pareigūnų ataskaita), „Lietuvos istorijos studijos” 27, 2011, s. 164-178; T. Čelkis, Lietuvos Didžiosios Kunigaikštystès teritorija. Sienu samprata ir delimitaciniai procesai XIV-XVI amžiuje, Vilnius 2014.

${ }^{2}$ L. Bucevičiūtè, Lietuvos Didžioji Kunigaikštystè XV-XVI a. Valstybès erdvés ir jos sienu samprata. Mokslo monografija, Kaunas-Vilnius 2015; eadem, Lietuvos valstybes teritoriniai kontaktai rytuose $X V-X V I$ a. Keletas sienu istorijos epizodu,, „Istorija” 78, 2010, $\mathrm{nr} 2$, s. 3-14; eadem, Stepés teritorine specifika XVII-XVIII a. Geografinis ir kartografinis aspektas, „Darbai ir dienos” 61, 2014, s. 213-232; eadem, Valstybès erdvés samprata Lietuvos Didžiosios Kunigaikštystés teisés dokumentuose (XV-XVI a.), „Lietuvos istorijos metraštis” 1, 2009 [2010], s. 51-68.
} 
a później Księstwa Prus, zostały omówione - z różnej perspektywy - w historiografii niemieckiej, polskiej i litewskiej.

Jako przykład można tu przywołać prace: Kurta Forstreutera ${ }^{3}$, Hansa Jürgena Karpa ${ }^{4}$, Zbysława Wojtkowiaka ${ }^{5}$, Macieja Dorny ${ }^{6}$, Władysława Pociechy ${ }^{7}$, Janusza Małłka ${ }^{8}$, Adama Szwedy ${ }^{9}$, Zenonasa Ivinskisa ${ }^{10}$ i Rokasa Varakauskasa ${ }^{11}$. Bogata jest również historiografia zagadnienia granic Litwy i Polski. Tutaj można wymienić prace: Jana Jakubowskiego ${ }^{12}$, Aliny Wilkiewicz-Wawrzyńczykowej ${ }^{13}$, Doroty Michaluk ${ }^{14}$, Józefa Maroszka ${ }^{15}$. Problemom wschodniej i południowej granicy Wielkiego Księstwa Litewskiego szczególną uwagę poświęcili autorzy rosyjscy, ukraińscy, białoruscy i polscy. W fundamentalnych studiach Jana Natansona-Leskiego, poświęconych zmianom granic Litwy i Państwa Moskiewskiego

${ }^{3}$ K. Forstreuter, Die Entwicklung der Grenze zwischen Preußen und Litauen seit 1422, „Altpreußische Forschungen" 18, 1941, nr 1, s. 50-70.

${ }^{4}$ H.J. Karp, Grenzen in Ostmitteleuropa während des Mittelalters, Köln 1972.

${ }^{5}$ Z. Wojtkowiak, Pótnocna granica Litwy wśredniowieczu. „Limites inter Litvaniam et Livonia” z 1473, w: Poznań - Wilnu. Studia historyków w roku tysiąclecia Państwa Litewskiego, red. Z. Wojtkowiak, Poznań 2010, s. 213-270; idem, Lithuania Transwilniensis saec. XIV-XVI. Podziały Litwy pótnocnej w późnym średniowieczu, Poznań 2005; idem, Delimitacja litewsko-kurlandzka z 1584 roku, „Lituano-Slavica Posnaniensia Studia Historica” 3, 1989, s. 270-276; idem, Dryświaty - rubież litewska w średniowieczu, „Lituano-Slavica Posnaniensia. Studia Historica” 1, 1985, s. 115-139.

${ }^{6}$ M. Dorna, Akt delimitacji litewsko-inflanckiej $z 7$ lipca 1473 roku, ,Lituano-Slavica Posnaniensia Studia Historica" 14, 2013, s. 87-102.

${ }^{7}$ W. Pociecha, Królowa Bona (1494-1557). Czasy i ludzie odrodzenia, t. 3, Poznań 1958.

8 J. Małłek, Granice państwowe, kościelne i administracyjne Prus Książęcych w XVI w., „Komunikaty Mazursko-Warmińskie" 1966, nr 1, s. 131-139.

9 A. Szweda, Methoden der Schlichtung von Grenzstreitigkeiten zwischen Polen-Litauen und dem Deutschen Orden nach Abschluss des Friedens von Brześć im Jahre 1435. Am Beispiel des in Toruń und Nieszawa wirkenden Grenzgerichts, w: Grenze und Grenzüberschreitung im Mittelalter. 11. Symposium des Mediävistenverbandes vom 14. bis 17. März 2005 in Frankfurt an der Oder, Berlin 2007, s. 54-65.

${ }^{10}$ Z. Ivinskis, Lietuvos istorija. Iki Vytauto Didžiojo mirties, Vilnius 1991; idem, Kovos bruožai dèl Žemaičiu ir ju sienu, „Athenaeum” 6, 1936, s. 54-117; idem, Lietuvos valstybingumo išplètimas slavu erdveje, „Tautos praeitis” 1, 1962, nr 4, s. 501-502.

${ }^{11}$ R. Varakauskas, Lietuvos ir Livonijos santykiai XIII-XVI a., Vilnius 1982; idem, Lietuvos ir Livonijos santykiu po Pabaisko mūšio klausimu, „Lietuvos TSR aukštųjų mokyklų mokslo darbai. Istorija" 14 , 1974, s. 45-59.

12 J. Jakubowski, Przykład zmienności granic administracyjnych na Litwie w w. XVI, „Ateneum Wileńskie" 10, 1935, s. 161-164.

13 A. Wilkiewicz-Wawrzyńczykowa, Spory graniczne polsko-litewskie w XV-XVII w., Wilno 1938, s. $97-102$.

${ }^{14}$ D. Michaluk, Ziemia mielnicka województwa podlaskiego w XVI-XVII wieku. Osadnictwo, własność ziemska i podziały kościelne, Toruń 2002; eadem, Памежныя спрэчки памиж Каронай і Вялікім Княствам Літоўскім у 16-17 стот. На прыкладзе Мельницкай и Берасцейскай земляў, „Гістарычны альманах” 5, 2001, s. 23-53.

${ }^{15}$ J. Maroszek, Pogranicze Litwy i Korony w planach króla Zygmunta Augusta: z historii dziejów realizacji myśli monarszej między Niemnem a Narwią, Białystok 2000. 
w okresie panowania Jagiellonów i Stefana Batorego, zawarto konceptualny obraz granicy, z uwzględnieniem najważniejszych czynników politycznych i geopolitycznych $\mathrm{w}$ regionie, które miały wpływ na różne rozwiązania międzypaństwowe ${ }^{16}$. Szczególnie istotne dla analizowanego tu zagadnienia są wnioski białoruskiego historyka i kartografa Wiktora Tiemuszewa. Jego ważne badania poświęcone zostały rzece Ugrze jako pewnej granicy socjogeograficznej oraz psychologicznej, rozdzielającej Litwę od Państwa Moskiewskiego ${ }^{17}$. Najważniejszymi studiami poświęconymi zagadnieniu granicy południowej Wielkiego Księstwa oraz problematyce stepów są prace Mychajła Hruszewśkiego ${ }^{18}$, Fiodora Petrunia ${ }^{19}$, Feliksa Szabuldo $^{20}$, Michała Żdana ${ }^{21}$, Bertolda Spulera ${ }^{22}$ i Andrzeja Dziubińskiego ${ }^{23}$.

${ }^{16}$ J. Natanson-Leski, Dzieje granicy wschodniej Rzeczypospolitej. Granica moskiewska w epoce Jagiellońskiej, cz. 1, Lwów-Warszawa 1922; idem, Epoka Stefana Batorego w dziejach granicy wschodniej Rzeczypospolitej, Warszawa 1930.

${ }^{17}$ В.Н. Темушев, Феномен московско-литовского порубежья XV в., w: Вялікае княства Літоусккае і яго суседзі у XIV-XV стст. Саперніцтва, супрацойніцтва, урокі: да 600-годдзя Грунвальдскай бітвы: матэрыялы Міжнар. навук. канф. (Гродна, 8-9 ліп. 2010 г.), Мінск 2011, s. 199-206; ideт, Река Угра - вековой страж московско-литовской границы, w: Новая локальная история. Пограничные реки и культура берегов. Материаль второй Международной Интернет-конференции. Ставрополь, 20 мая 2004 г., Ставрополь 2004, s. 305-317; idem, Формирование московско-литовской границьь в XV - начале XVI в., „Studia Historica Europae Orientalis. Исследования по истории Восточной Европы, Научный сборник” 1, 2008, s. 56-76; idem, Сведения о московско-литовском пограничье в посольских книгах времени Ивана III, w: Труды кафедры истории России с древнейших времен до XX века, Санкт Петербург 2006, s. 294-306; idem, К вопросу о московско-литовской границе XV в. (владения князей Крочинских), „Ruthenica” 2007, nr 6, s. 299-307; idem, К вопросу о московско-литовской гранище XV в. (владения князей Крошинских), „Древняя Русь. Вопросы медиевистики” 2005, nr 3(21), s. 102-103; idem, „Вайна пад час міру”. Першая памежная вайна ВКЛ з Масквою (1486-1494), „Беларускі Гістарычны Агляд” 15, 2008, s. 5-48; idem, Гомельская земля в конце XV - первой половине XVI в. Территориальные трансформации в пограничном регионе, Квадрига 2009; idem, На ўсходняй мяжы Вялікага Княства Літоўскага (сярэдзіна XIV - першая палова XVI cm.), Смаленск 2014.

${ }_{18}$ М. Грушевський, Історія Украйни-Руси, t. 4, Киів-Львів 1907; idem, Южнорусскіе господарскіе замки въ половине XVI века, „Историко-статистическій очеркъ. Университетския известія” 30, 1890, nr 2, s. 1-33.

${ }^{19}$ Ф. Петрунь, Східня межа Великого Князівства Литовского в 30-х роках XV сторіччя, w: Збірник Історично-філологічного відділу УАН. Ювілейний збірник на почану акад. М.С. Грушевського, Київ 1928, s. 165-168; idem, Нове про татарську старовину Бозько-Дністрянського степу, „Східний світ” 1928, nr 6, s. 162-263; іdет, Ханські ярлики на украйнські землі (До питання про татарську Україну), „Східний світ” 1928, nr 2, s. 172.

${ }^{20}$ F. Šabuldo, „Semiono žmonès”. Ju teritorija ir vaidmuo Krymo ir Lietuvos politiniuose santykiuose XV a. pabaigoje, „Lietuvos istorijos metraštis” 1, 2010 [2011], s. 5-21; Ф.М. Шабульдо, „Семеновы люди". Их территория и роль в политических отночениях между Крымом и Литвой на исходе XV века, „Ruthenica” 2010, nr 9, s. 57-73; idem, Земли Юго-Западной Руси в составе Великого княжества Литовского, Киев 1987.

${ }^{21}$ M. Żdan, Stosunki litewsko-tatarskie za czasów Witołda, w. ks. Litwy, „Ateneum Wileńskie” 7, 1930, nr 3-4, s. 529-601. 
Najistotniejszymi źródłami, które pozwoliły na rekonstrukcję specyfiki pojęcia granic i pograniczy państwa litewskiego oraz jego sąsiadów, są różnego rodzaju materiały aktowe dotyczące delimitacji, posiadające moc prawną umowy międzynarodowe, regulujące zagadnienia granic państwowych. Dokumenty te pomieszczone zostały w różnych zbiorach tekstów źródłowych, do których odnośniki można będzie znaleźć w dalszej części tekstu.

Celem niniejszego artykułu jest przedstawienie specyfiki pojęcia granic i pograniczy Litwy oraz jej sąsiadów w XV-XVI w., ukazanie podobieństw i różnic w rozwoju granic, a także wskazanie najważniejszych czynników, które wpłynęły na regionalne zróżnicowanie rozwoju granic państwa.

\section{Etapy rozwoju granic państwa litewskiego}

Na początek zostanie zaprezentowanych kilka uwag o początkach tworzenia się terytorium Litwy. Przede wszystkim należy wspomnieć o czynnikach, które wpłynęły na konieczność wyznaczenia granic. Należy ponadto omówić okres, w którym pojawiło się pojęcie granic państwowych.

Państwo litewskie kształtowało się na podstawie ziem plemiennych, które również posiadały swoje granice, najczęściej wykorzystujące punkty geograficzne. Można stwierdzić, że różne przeszkody naturalne po prostu oddzielały obszary zamieszkane przez różne społeczności i był to najbardziej wyrazisty element pojęcia granic miejsca zamieszkania. Władca Litwy Mendog zjednoczył te ziemie w większy twór terytorialny - państwo litewskie. Już w drugiej połowie XIII w. ze źródeł historycznych zaczynają zanikać, a w XIV w. znikają całkowicie nazwy poszczególnych ziem Litwy. Kształtujące się w XIV w. terytorium Wielkiego Księstwa tworzyły ziemie jednoczone przez władcę. Ten związek terytorialny oddzielały od innych ziem obiekty geograficzne o znacznym rozmiarach, np. masywy leśne, zbiorniki wodne, bagna. Poszczególne obszary osadnicze oddzielały duże, niezamieszkałe przestrzenie. Pogranicza zamieszkałych terytoriów odpowiadały pierwszym granicom państwowym ${ }^{24}$.

${ }^{22}$ B. Spuler, Mittelalterliche Grenzen in Osteuropa. I. Die Grenze des Großfürstentums Litauen im Südosten gegen Türken und Tataren, „Jahrbücher für Geschichte Osteuropas” 1941, z. 2/4, s. $152-170$.

${ }^{23}$ A. Dziubiński, Stosunki dyplomatyczne polsko-tureckie w latach 1500-1572 w kontekście międzynarodowym, Wrocław 2005, s. 117-123, 175-188; idem, Polsko-litewskie napady na tureckie pogranicze czarnomorskie w epoce dwu ostatnich Jagiellonów, „Kwartalnik Historyczny” 103, 1996, nr 3, s. $53-86$.

${ }^{24}$ Szerzej zob.: H. Łowmiański, Studia nad dziejami Wielkiego Księstwa Litewskiego, Poznań 1983, s. 51-66, 84-99; idem, Studja nad początkami społeczeństwa i państwa litewskiego, t. 1, Wilno 1931, s. 24-27, 95-96, 426-434; t. 2, 1932, s. 82-128, 140-144; E. Gudavičius, Mindaugas, Vilnius 1998, s. $138-176$. 
Powstaje w tym miejscu pytanie, kiedy i w jakich okolicznościach politycznych na Litwie zaistniała konieczność przejścia od granic naturalnych do ustalonych w wyniku konkretnych umów?

Ważną przyczyną pojawienia się tego zjawiska były procesy kolonizacyjne. W okresie formowania się państwa i kolonizacji niezamieszkałych rubieży nieuchronnie następowała konfrontacja $\mathrm{z}$ obcą siłą polityczną, która zmuszała do negocjacji i ustalenia granic. W przypadku Litwy bardzo ważnym czynnikiem było jej sąsiedztwo z zakonem krzyżackim. Zakon tworzył w tym czasie jedno z najnowocześniejszych pod względem organizacji terytorialnej państw w Europie. Określa się je państwem terytorialnym, ponieważ aparat władzy zakonu był całkowicie niezależny od stosunków rodzinnych, państwem władali zakonnicy, którzy charakteryzowali się bardzo silną świadomością polityczną. Z tego względu państwo zakonne znacznie różniło się od tradycyjnych państw feudalnych, u którego podstaw leżały związki rodzinne władcy ${ }^{25}$.

Państwo zakonu krzyżackiego, założone nad Bałtykiem w XIII w., od początku dużą wagę przywiązywało do swojego terytorium. Najpierw ustaliło granice z Polską i Mazowszem ${ }^{26}$. Przez długi czas zakon nie był zainteresowany negocjowaniem granic z Litwą, bo celem było jej podbicie. Pierwsze granice terytorialne z Litwą zakon ustalił jednostronnie, ustanawiając po prostu na zajętych ziemiach swoją administrację.

Dla rozwoju granic i terytorium państwa litewskiego istotną kwestią jest przedstawienie poszczególnych etapów tego procesu, które poniżej przedstawię. Etap pierwszy to początek kształtowania się terytorium państwa litewskiego, łączony z czasami Giedymina, Olgierda i Kiejstuta. Należy uwypuklić przede wszystkim

${ }^{25}$ B. Arnold, Princes and Territories in Medieval Germany, Cambridge 1991, s. 61-76, 248-279; E. Schubert, Fürstliche Herrschaft und Territorium im späten Mittelalter, München 2006, s. 1-26; idem, Der Rätselhafte Begriff „Land” im späten Mittelalter und in der frühen Neuzeit, „Concilium Medii Aevi" 1998, s. 15-27; R. Wenskus, Das Ordensland Preussen als Territorialstaat des 14. Jahrhunderts, w: Ausgewählte Aufsätze zum frühen und preußischen Mittelalter, red. H. Patze, Sigmaringen 1986, s. 347-382.

${ }^{26}$ Szczegółowo politykę graniczną oraz układy pomiędzy zakonem krzyżackim i Mazowszem omówiono w serii artykułów polskich badaczy Elżbiety Kowalczyk i Wiesława Długokęckiego, opublikowanych w „Kwartalniku Historycznym”: E. Kowalczyk, Rajgród 1360 r. Przyczynek do dziejów granicy mazowiecko-krzyżackiej, „Kwartalnik Historyczny” 113, 2006, nr 3, s. 5-18; W. Długokęcki, E. Kowalczyk, Opis granicy Mazowsza z państwem zakonu krzyżackiego, „Kwartalnik Historyczny" 109, 2002, nr 2, s. 5-14; iidem, Nieznane opisy granicy mazowiecko-krzyżackiej, cz. I: Granice komornictwa działdowskiego i nidzickiego, „Kwartalnik Historyczny” 110, 2003, nr 1, s. 29-50; iidem, Nieznane opisy granicy mazowiecko-krzyżackiej, cz. II: Granica komturstwa bałgijskiego (prokuratorstwo piskie i ełckie), „Kwartalnik Historyczny” 2004, 111, nr 1, s. 5-37; zob. też E. Sandow, Die polnisch-pommerellische Grenze 1309-1454, Kitzingen am Main 1954; A. Szweda, Królestwo Polskie a zakon krzyżacki 1348-1350 - między konfliktem a współdziałaniem, „Zapiski Historyczne" 77, 2012, nr 1, s. 9-24. Brak natomiast jakiejkolwiek literatury dla odcinka polskiego, gdzie mamy umowę graniczną z 1349 r.; E. Sandow, op. cit.; A. Szweda, Królestwo Polskie a zakon krzyżacki... 
okres władzy Olgierda i Kiejstuta, gdyż w ich czasach nastąpił zwrot ku dwustronnej negocjacji granic. Właśnie za panowania tych władców podjęto działania na poziomie międzypaństwowym w celu uformowania zachodnich granic Wielkiego Księstwa. Zawarto pierwsze dwustronne umowy, które regulowały przynależność państwową poszczególnych obszarów. Na przykład w 1358 r. prowadzono rozmowy dotyczące granicy z Mazowszem ${ }^{27}$. Jest to okres kształtowania się pojęcia granic państwowych Litwy, gdy zrozumiano, że władza rozciąga się nie tylko na ludzi, ale także na konkretne terytorium, którego należy bronić, a do tego potrzebne są wyznaczone granice.

Etap drugi związany jest z okresem rządów Witolda do mniej więcej połowy XV w. Charakterystyczne dla tego czasu jest wykształcenie się pojęcia granicy linearnej, a także umowy międzypaństwowe zawierane nie tylko z zakonem, ale również z księstwami ruskimi, Moskwą i Polską.

W umowach o pokoju wieczystym zawartych w 1398 r. na wyspie Salin ${ }^{28}$ oraz w 1422 r. nad jeziorem Mełno ${ }^{29}$ po raz pierwszy w oddzielnych artykułach zawarto opisy granic państwa, których typ jest już bliski pojęciu granicy linearnej. Najważniejszymi cechami tego typu rozgraniczenia jest stosowanie sztucznych wyznaczników i wyliczanie odległości między nimi. Przeprowadzona w czasach Witolda akcja wytyczenia granicy z państwem zakonnym była nowym jakościowo etapem rozwoju pojęcia granicy, które oznaczało również zdefiniowanie nowego terminu terytorium państwa ${ }^{30}$.

Już od drugiej połowy XIV w. kształtowały się granice Wielkiego Księstwa i Mazowsza, na które wpływ miały także procesy delimitacyjne zachodzące między

${ }^{27}$ Umowa pomiędzy Wielkim Księstwem Litewskim a Mazowszem, 14 VIII 1358 r., w: Nowy kodeks dyplomatyczny Mazowsza, t. 3: Dokumenty z lat 1356-1381, wyd. I. Sułkowska-Kuraś, S. Kuraś, Warszawa 2000, nr. 24, s. 30-32; Kodeks dyplomatyczny księstwa Mazowieckiego, obejmujący bulle papieżów, przywileje królów polskich i książąt mazowieckich, tudzież nadania tak korporacyj jako i osób prywatnych, wyd. J.T. Lubomirski, Warszawa 1863, nr 80, s. 72-75.

28, „[... ab hinc linealiter et directe eundo ad quendam lapidem magnum dictum Roda [...]. Apeytensehe, a dicto lacum stagno per directum eundo usque ad uulgariter nuncupatam der Brengelische weg", traktat pokojowy zawarty na wyspie Salin, 1398 r., w: Kodex dyplomatyczny Litwy, wyd. E. Raczyński, Wrocław 1845, s. 254-255.

${ }^{29}$ Pokój mełneński, 27 IX 1422 r., w: Dokumenty strony polsko-litewskiej pokoju metneńskiego z 1422 roku, wyd. P. Nowak, P. Pokora, Poznań 2004, s. 2-10; Codex diplomaticus Regni Poloniae, t. 4, wyd. M. Dogiel, Vilnae 1764, nr 90, s. 110-115; Die Staatsverträge des Deutschen Ordens in Preussen im 15. Jahrhundert, t. 1: 1398-1437, wyd. E. Weise, Königsberg 1939, nr 152-154, s. 157-164; Liv-, esth- und curländisches Urkundenbuch nebst Regesten, t. 5: 1414-1423, wyd. F.G. von Bunge, Riga 1867, nr 2637, s. 880-881; Skarbiec diplomatów papiezkich, cesarskich, krolewskich, książęcych; uchwał narodowych, postanowień różnych władz i urzędów posługujących do krytycznego wyjaśnienia dziejów Litwy, Rusi Litewskiéj i ościennych im krajów, t. 2, oprac. I. Daniłowicz, Wilno 1862, nr 1359, s. 79-80.

${ }^{30}$ Szerzej zob.: T. Čelkis, Lietuvos Didžiosios Kunigaikštystės teritorija..., s. 133-136; L. Bucevičiūtè, Lietuvos Didžioji Kunigaikštystè..., s. 199-209. 
Mazowszem a państwem zakonnym. W XV w. widać również dążenie do ustalenia precyzyjnej granicy pomiędzy Litwą i Polską ${ }^{31}$. Najważniejszym czynnikiem była tu kolonizacja wewnętrzna na niezamieszkałej przestrzeni nadgranicznej. Tutaj również możemy zaobserwować cechy charakterystyczne dla rozwoju granic linearnych ${ }^{32}$.

Warto podkreślić, że formowanie się granic linearnych jest charakterystyczne jedynie dla zachodnich, południowo-zachodnich i północnych pograniczy Litwy. Ustalenie granic z Moskwą miało odmienną specyfikę. Delimitacja odbywała się tam poprzez podbój. Jedną z ważniejszych cech polityki litewskiej w zakresie granic wschodnich było dzielenie terytorium według konkretnych spisów, nie wyznaczając linii granicznej. Inaczej niż z państwem zakonnym, z Moskwą nie zawierano specjalnych układów granicznych, poprzestając na uregulowaniach zawartych w układach rozejmowych lub pokojowych ${ }^{33}$.

W księstwach ruskich istniało pojęcie władzy, znane jeszcze z okresu istnienia Rusi Kijowskiej. W źródłach często wspominane jest zachowanie „starego”, czyli byłego, stanu. Oznaczało to przetrwanie samych księstw ruskich. Dlatego po zdobyciu i przyłączeniu jakichś terytoriów dysponowano nimi jako niepodzielnymi jednostkami, sporadycznie jedynie je rozdzielając. Na przykład w pierwszej umowie pokojowej zawartej między Litwą i Moskwą, z 1449 r., wymieniono terytoria, które przechodziły do każdego z państw - dysponowano nimi jak niepodzielnymi jednostkami ${ }^{34}$. Ustalenie tych granic miało określoną specyfikę, opartą wyłącznie na zasadzie zdobyczy terytorialnych.

W czasie panowania Witolda wynegocjowane zostały również granice z południowymi sąsiadami. W 1398 r. chan tatarski Tochtamysz w oddzielnym dokumencie przekazał Witoldowi prawa do terytorium między Dniestrem a Dnieprem ${ }^{35}$. To porozumienie dotyczyło obszaru wyznaczonego wyłącznie na podstawie naturalnych punktów geograficznych.

Trzeci etap rozwoju granic Litwy obejmuje drugą połowę XV w. To okres, w którym obserwujemy tendencje do rewizji granic z północnymi, zachodnimi i południowo-zachodnimi sąsiadami. Możemy dostrzec również zainteresowanie doskonaleniem techniki ustalania granic. Odnowa granic oznaczała, że nie przeprowadzano zasadniczych dyskusji o przebiegu linii granicznej, a uwagę skupiano

31 T. Čelkis, Lietuvos Didžiosios Kunigaikštystès teritorija..., s. 280-282; A. Wilkiewicz-Wawrzyńczykowa, op. cit., s. 103.

${ }^{32}$ L. Bucevičiūtè, Lietuvos Didžioji Kunigaikštystè..., s. 223-230.

${ }^{33}$ Ibidem, s. 302-308.

${ }^{34}$ Umowa pomiędzy WKL a Moskwą, 1449 r., w: Акть, относящиеся к истории Западной Poсcuu, t. 1-2, Санкт Петербург 1846, nr 50, s. 63; zob. też Lietuvos Metrika. Knyga Nr. 5: 1427-1506; Užrašymų knyga 5, wyd. E. Banionis, Vilnius 1993, nr 87.1, s. 131-133.

35 T. Čelkis, Valdžia ir erdvé: Lietuvos Didžiosios Kunigaikštystès teritorializacijos procesas XIV-XVI a. Disertacija, Vilnius 2011, s. 253-254. 
na poprawkach i korektach. Jako przykład charakterystyczny dla odnowy granic można wskazać umowę graniczną zawartą z Inflantami w $1473 \mathrm{r} .{ }^{36}$ To pierwszy tego typu układ w całości poświęcony wyłącznie delimitacji, nie poruszono w nim jakiegokolwiek innego zagadnienia. Tym razem granica między Litwą a Inflantami została wyznaczona przy pomocy wielu sztucznych obiektów, pomiędzy którymi wymierzono odległości w milach.

Należy jednak zauważyć, że na tym etapie nie odnotowujemy żadnych śladów odnowy granic na wschodzie czy południu. W latach 1440-1449 wielki książę litewski Kazimierz Jagiellończyk, zawierając umowy z Moskwą, Twerem i Nowogrodem, starał się jeszcze zachować granice z czasów Witolda, jednak wraz ze wzmocnieniem się Moskwy wschodnie terytorium Litwy przekształciło się w znacznym stopniu. Już w końcu XV w., na podstawie traktatu pokojowego z 1494 r., Wielkie Księstwo zrezygnowało z pretensji do Nowogrodu, Pskowa, Tweru, Wiaźmy, straciło prawie całe terytorium górnego biegu Oki i jeszcze wiele innych terytoriów ${ }^{37}$. Warto zwrócić uwagę, że również w tym czasie podział ziem w układach z Moskwą odbywał się zgodnie ze spisami, w których figurowały niepodzielne jednostki terytorialne i nie występowały cechy charakterystyczne dla granicy linearnej.

Po tym jak w 1475 r. suwerenem Chanatu Krymskiego został sułtan z dynastii Osmanów Mehmed II, zintensyfikowały się tatarskie wypady na terytorium Wielkiego Księstwa. W 1484 r. sułtan Bajazyd II zajął część sąsiadującej z nim Mołdawii z portem Kilia w delcie Dunaju oraz port Białogród nad Dniestrem ${ }^{38}$. W 1486 r. Mołdawia została wasalem Osmanów, w ten sposób Turcy osiągnęli granicę Litwy, którą w tym czasie był dolny bieg Dniestru ${ }^{39}$. W drugiej połowie $\mathrm{XV}$ w. litewskie elity polityczne miały już niewątpliwie wyobrażenie o swoich południowych granicach. Najważniejszą rolę odgrywało naturalne środowisko geograficzne oraz historyczne przywiązanie do granic z czasów Witolda. Źródła z połowy XVI w. pozwalają twierdzić, że w połowie wcześniejszego stulecia Wielkie Księstwo zdołało w tej części państwa zbudować i udokumentować swoje granice. Jest to związane z okresem rządów w Kijowie Szymona Olelkowicza $(1454-1470)^{40}$. Ustalono wówczas granice południowe i południowo-wschodnie, wykorzystując niemal wyłącznie naturalne obiekty geograficzne. Na ich podstawie

\footnotetext{
${ }^{36}$ Akt delimitacyjny pomiędzy WKL i Inflantami, 3 VII 1473 r., w: Limites Regni Poloniae et Magni Ducatus Lituaniae, wyd. M. Dogiel, Vilnae 1758, s. 207-211; Codex diplomaticus Regni Poloniae, t. 5, wyd. M. Dogiel, Vilnae 1759, nr 82, s. 142-143; Lietuvos Metrika. Knyga nr. 5 (1427-1506)..., nr 125, s. 235-238; Skarbiec diplomatów papiezkich..., t. 2, nr 1980, s. 214.

${ }^{37}$ Umowa pomiędzy WKL a Moskwą, 5 II 1494 r., w: Духовныя и договорныя грамоты великихъ и удпльныхъ князей XIV-XVI вв., Москва 1950, nr 83, s. 329-332.

38 Umowa z 1486 r., w: Акты, относящиеся к истории Западной России..., t. 1, nr 88, s. 107.

${ }^{39}$ Zob. mapa w: A. Dziubiński, Stosunki dyplomatyczne polsko-tureckie..., s. 34; T. Čelkis, Lietuvos Didžiosios Kunigaikštystés teritorija..., s. 259-260.

40 Ф.М. Шабульдо „Семеновы люди”..., s. 63.
} 
Laima Bucevičiūtè

wyznaczony został kontur granic przyrodniczych. Jednak ze względu na brak źródeł nie możemy dokładniej ocenić i zanalizować okoliczności ich ustalenia.

Czwarty etap rozwoju granic Litwy jest związany z XVI w. Cechą charakterystyczną dla tego okresu jest stabilizacja tych granic i wzmocnienie politycznego autorytetu państwa. Obserwujemy próby nie tylko odnowy, ale również rewizji wszystkich granic państwowych. Za pomocą umów dwustronnych próbowano zweryfikować całość terytorium państwa. Jest to już etap charakterystyczny dla istnienia zunifikowanego terytorium państwowego.

Szczególnie widoczne jest to w przypadku granicy litewsko-polskiej. W pierwszej połowie XVI w. niezwykle intensywnie kolonizowane były obszary między obu państwami - solitudo, desertum - czyli pustkowia. Dochodziło wówczas do wielu przypadków nielegalnej kolonizacji, a naruszanie granicy prowadziło do konfliktów między mieszkańcami pogranicza, które rozwiązywali wyznaczeni komisarze, weryfikując i odnawiając granice. Już w dokumencie z 1519 r. wspomina się o rewizji granicy pomiędzy Koroną a Litwą ${ }^{41}$, a w 1529 r. została konsekwentnie ustalona na nowo cała granica państwa ${ }^{42}$. Wyjątkowy jest w tym względzie rok 1546, kiedy przeprowadzono proces rewizji i odnowienia całej granicy państwowej. Dokładności wytworzonej wówczas dokumentacji nie dorównują materiały żadnego procesu delimitacji z XV-XVI w. ${ }^{43}$

$\mathrm{W}$ procesie odnowy granicy z Prusami bardzo ważne było rozgraniczenie z 1545 r. ${ }^{44} \mathrm{Na}$ nowo sformowana pomiędzy państwami, zgodnie z dyspozycją obu władców, linia graniczna uzyskała już formę i cechy charakterystyczne dla dzisiejszej praktyki demarkacyjnej: wspomina się o murowanym słupie z heraldyczną symboliką państwową i napisami. Dla oznaczenia linii granicznej pomiędzy Wielkim Księstwem a Inflantami podczas delimitacji z 1541 r. również użyto murowanych słupów. Taki znak może już być uznany za przejaw powstawania zunifikowanego systemu znaków granicznych. Po raz kolejny granicę między Litwą a Inflantami odnowiono w $1545 \mathrm{r}^{45}$ Wówczas również wspominano znak graniczny - murowany słup z herbami państwowymi.

$\mathrm{Na}$ tym etapie ważne efekty osiągnięto również w stosunkach z południowymi sąsiadami. W latach 30. XVI w. Osmanowie umocnili się na wybrzeżu Morza

${ }^{41}$ Dok. z 1519 r., w: Acta Tomiciana, t. 5: 1519-1521, Posnaniae 1855, nr 15, s. 12.

42 Dok. z 1529 r., w: Acta Tomiciana, t. 11: 1529, Posnaniae 1901, nr 59, s. 54.

${ }^{43}$ Dok. ustalający granicę między Litwą i Polską, 3 VIII 1546 r., w: Археографический сборник документов, относящихся к истории Северозападной Руси, t. 1, Вильна 1867, nr 31, s. $46-126$.

${ }^{44}$ Odnowienie granicy między Litwą i Księstwem Prus, VIII 1545 r., w: Книга Посольская Метрики Великого княжества Литовского, содержащая в себе дипломатические сношения Литвы в государствование короля Сигизмунда Августа (с 1545 по 1572 год), wуd. М. Оболенский, И. Данилович, Москва 1843, nr 7, s. 6-7; nr 8, s. 7-8; nr 9, s. 8-9; nr 10, s. 9-11; nr 12, s. 12-13; nr 13, s. 13-14; nr 14, s. 14-16.

${ }^{45}$ Najnowsza publikacja dok. i badania: T. Čelkis, D. Antanavičius, op. cit., s. 164-178. 
Czarnego pomiędzy Dniestrem i Dnieprem, które litewskie elity traktowały jako przynależne do ich państwa. Ważne jest rozgraniczenie z 1542 r., które ukazuje, że negocjacje granicy Litwy na południu weszły w nowy jakościowo etap ${ }^{46}$. Właśnie $\mathrm{w}$ tejże delimitacji wykorzystano wspomniany opis granicy z połowy XV w., w którym dominował spis naturalnych obiektów geograficznych. Po prostu przepisano wypis z delimitacji granic i dostosowano do okoliczności negocjacji. Wyznaczenie granic Polski i Litwy z Imperium Osmańskim świadczyło o oczywistej konieczności rozwiązania zagadnienia granicznego - ustalenia przebiegu granicy. W tym dialogu politycznym brało udział Imperium Osmańskie - istotna lokalna siła polityczna, dysponująca scentralizowanym aparatem administracyjnym, a nie pojedyncze ordy tatarskie. Prowadzący koczowniczy tryb życia Tatarzy przestrzeń swojego państwa rozumieli bardzo abstrakcyjnie i nie widzieli konieczności wytworzenia namacalnego związku z zamieszkiwanym przez nich terytorium. To zasadnicza różnica między akcją ustalania granic z ordami czy Chanatem Krymskim za czasów Witolda i wcześniejszych a negocjowaniem granic z Turkami w połowie XVI w. Z drugiej strony, te zawarte w połowie XVI w. uzgodnienia graniczne z Turkami nie oznaczały stabilności tych granic, co było typowe dla granic na zachodzie, południowym zachodzie i północy. Wciąż jeszcze nie było skolonizowanego pogranicza, które mogło ograniczać mobilność mieszkańców sąsiadujących ze sobą państw.

\section{Zagadnienie granic i pograniczy państwa litewskiego $\mathrm{z}$ perspektywy procesu ich rozwoju}

Podsumowując rozważania historiografii poświęconej studiom nad granicami, można uznać, że granice linearne formują się ostatecznie w wyniku realizacji programu wojenno-obronnego, społeczno-ekonomicznego i kulturalno-ideologicznego opanowania terytorium.

\footnotetext{
${ }^{46}$ Ustalenie przebiegu granic Wielkiego Księstwa Litewskiego na południu. Niedatowany dokument pierwszy raz opublikowano w połowie XIX w. w zbiorze źródeł: Акты, относящиеся к истории Западной России..., t. 2, nr 199, s. 361-362. Wydawcy błędnie wskazali datę dokumentu - 1540 r., gdyż został on znaleziony wśród dokumentów z tego roku. Według F. Szabuldo polskojęzyczna kopia tego dokumentu z XVIII w., znajdująca się w zbiorach Naruszewiczów, jest datowana na 1542 r.; zob. AGAD, Teki Naruszewicza, t. 6, Akta historyczne z lat 1530-1544, k. 266-266v.; zob. F. Šabuldo, op. cit., s. 11. Ten opis granicy, transkrybowany na polski, został ogłoszony przez Macieja Dogiela w zbiorze: Limites Regni Poloniae..., s. 61-62. Publikowany dokument również nie jest datowany. Ten sam dokument, datowany na rok 1542, został opublikowany również w ks. 17 spraw sądowych Metryki Litewskiej: Lietuvos Metrika (1540-1543); 12-oji Teismy bylu knyga (XVI a. pabaigos kopija), wyd. I. Valikonytè, N. Šlimienè, S. Viskantaitè-Saviščeviené, L. Steponavičienè, Vilnius 2007, nr 251, s. 214-215. W sprawie domniemanej daty 1542 zob. ibidem, nr 71, s. 81-82.
} 
$\mathrm{Na}$ etapie wojenno-obronnym tworzy się mechanizm kontroli wojskowej, który ma na celu zapewnienie stabilności na zajętym terytorium oraz obronę kresów jego terytorium i ustalenie strategiczno-wojskowej strefy nadgranicznej. Dalej następuje społeczno-ekonomiczny etap rozwoju granicy. Wówczas następuje kolonizacja i społeczna organizacja przestrzeni pogranicza. O zakończeniu tej części procesu świadczy wyraźnie zauważalna socjoekonomiczna różnica pomiędzy strefą nadgraniczną a otaczającymi ją obszarami oraz pojawienie się funkcji administracyjnych. Trzeci etap formowania się granic związany jest z kulturowymi oraz ideologicznymi kryteriami oceny i rozumienia granicy. O jego zrealizowaniu świadczy pojawienie się identyfikacji kulturowej społeczności pogranicza oraz jego charakterystycznej tożsamości. Część autorów twierdzi, że na tym etapie formowały się również zalążki charakteru narodowego. Po finalizacji tych stadiów możemy mówić o osiągnięciu całkowitej suwerenności terytorialnej i ostatecznym sformowaniu się przestrzeni politycznej. Zestawienie tych uwag historiograficznych ze wspomnianymi wcześniej etapami rozwoju terytorium i granic Wielkiego Księstwa ukazuje pewne rządzące tymi procesami reguły ${ }^{47}$.

Nie ma wątpliwości w kwestii wojskowo-obronnego i społeczno-ekonomicznego rozwoju zachodnich, południowo-zachodnich i północnych granic państwa litewskiego. Wspomniano już o intensywnej kolonizacji wewnętrznej i jej konsekwencjach w przypadku państwa zakonnego, a później Królestwa Prus i Polski.

Można mówić również o kulturalnym i ideologicznym aspekcie rozwoju granic, gdyż część granic państwa litewskiego z państwem zakonnym były granicami ziem centrum Litwy. Istniała społeczność pogranicza, posiadająca własną identyfikację społeczno-kulturalną, która wyraźnie odróżniała się od społeczności zamieszkującej po drugiej stronie granicy. Trzeba jeszcze wspomnieć o istotnej kwestii - wspomniana symbolika państwowa na znakach granicznych z połowy XVI w. również świadczyła o kulturalnej i ideologicznej dojrzałości państwa, charakterystycznej dla społeczeństwa posiadającego wyraźnie określone terytorium.

Rozwój granicy Wielkiego Księstwa z Państwem Moskiewskim właściwe nigdy nie wyszedł poza fazę pierwszą, pozostając na poziomie wojskowego opanowania terytorium. Można mówić jedynie o częściowej, społeczno-ekonomicznej identyfikacji z zamieszkałym terytorium. W połowie XVI w. na kilku odcinkach tej

\footnotetext{
${ }^{47}$ Szerzej zob.: N. Berend, Medievalists and the Notion of the Frontier, „The Medieval History Journal” 2, 1999, nr 55, s. 56-57; S. Elden, Land, Terrain, Territory, „Progress in Human Geography” 34, 2010, nr 6, s. 804-812; R.W. Etulain, Meeting Places, Intersections, Crossroads, and Borders. Toward a Complex Western Cultural History, „The Historian” 2004, 66, nr 3, s. 509-516; S.M. Jack, The 'Debatable Lands', terra nullius, and Natural Law in the Sixteenth Century, „Northern History” 41, 2004, nr 2, s. 289-290; R. Jones, Categories, Borders and Boundaries, „Progress in Human Geography” 33, 2009, nr 2, s. 185-186; idem, The Spatiality of Boundaries, „Progress in Human Geography" 34, 2010, nr 2, s. 263-267; L.D. Kristof, The Nature of Frontiers and Boundaries, "Annals of the Association of the American Geographers" 49,1959, nr 3, s. 269-282; P. Novak, The Flexible Territoriality of Borders, „Geopolitics” 2011, nr 16, s. 743-744.
} 
granicy możemy zaobserwować poważne napięcia społeczne, być może związane $\mathrm{z}$ większą koncentracją ludności w tych strefach. Należy jednak podkreślić, że w przypadku rozwoju granicy między Litwą a Moskwą nie można było oczekiwać naturalnych procesów kolonizacyjnych, gdyż mamy tu do czynienia ze stanem permanentnego konfliktu militarnego, związanego $\mathrm{z}$ moskiewskimi dążeniami do podbicia litewskiego terytorium. Co prawda w źródłach nie spotykamy zbyt często przypadków naruszenia granic i konfliktów granicznych. Doznane krzywdy i prośby rozwiązania sytuacji świadczą o zachodzących zmianach o charakterze kolonizacyjnym, jednak są to raczej pojedyncze epizody niż świadectwa systematycznych procesów. Granice linearne nie mogły wytworzyć się w sytuacji stale zmieniającej się przynależności politycznej tych terenów, tak jak w warunkach bezustannego konfliktu militarnego nie mogła się wykształcić społeczność mieszkańców pogranicza, z charakterystyczną dla niego tożsamością, odróżniającą ją od społeczności mieszkającej po drugiej stronie granicy.

Jeszcze trudniejsza jest ocena rozwoju granic Litwy z południowymi sąsiadami. Granice te odpowiadają jedynie kryteriom typowym dla wojskowo-obronnego etapu rozwoju. Na kształt południowej granicy państwa litewskiego istotny wpływ miała charakterystyczna przeszkoda naturalna w postaci stepu. Identyfikacja społeczno-ekonomiczna z zamieszkałym terytorium z założenia w tym przypadku nie mogła zaistnieć. Sieć zamków nadgranicznych i próby kolonizacji wojskowej mogą być jedynie bardzo ostrożnie oceniane jako częściowo spełniające to kryterium. Przypadek ustalenia granicy z Turkami w połowie XVI w. wskazuje na obecność samego pojęcia granicy, jednak warunki naturalne nadal odgrywały tutaj główną rolę $\mathrm{w}$ tworzeniu granic.

\section{Wnioski}

Podsumowując, wypada stwierdzić, że pojęcie granic państwa litewskiego zależało bezpośrednio od sąsiedztwa $\mathrm{z}$ innymi tworami politycznymi oraz modelu granicy wytworzonej w obszarze stosunków międzypaństwowych. W tym samym państwie w jednym momencie mogły współistnieć oba rodzaje granic: linearna i nielinearna (zwana również strefową).

Zamieszkałe, skolonizowane pogranicze jest najważniejszym warunkiem kształtującym granicę linearną. Tylko w momencie występowania dostatecznej podstawy społecznej i ekonomicznej granica dzieląca państwa mogła przekształcić się w liniową. Dokładność wyznaczania i wymierzania granicy linearnej warunkuje również intensywność kolonizacji wewnętrznej. W przypadku zamieszkiwania strefy nadgranicznej przez dużą liczbę osób przy wymierzaniu granicy skracane były odcinki graniczne wyznaczone przez większą ilość sztucznych znaków granicznych. 
Istnieje bezpośredni związek pomiędzy procesem kolonizacji i rywalizacji terytorialnej, co dobrze obrazuje proces ewolucji granicy litewsko-moskiewskiej. Brak stabilności politycznej wzmacniał uczucie tymczasowości, które powstrzymywało ludzi od osiedlania się w pobliżu granicy i zakładania tam stałych osad, w których z czasem można było znaleźć „starych mieszkańców” - ważnych świadków ustalenia, sprawdzenia i odnowy granic. Na początku XVI w. na zachodnich, południowo-zachodnich i północnych pograniczach taka sytuacja zdążyła już się wytworzyć, a na wschodnich, południowych i południowo-wschodnich - nie.

Stąd wiek XVI jest okresem stabilizacji granic Litwy z jej zachodnimi i północnymi sąsiadami. W tym okresie zagadnienia ustalenia granicy z zasady nie były już podnoszone, największą uwagę poświęcono ich odnowie i rewizji. $\mathrm{W}$ połowie XVI w. na granicach $\mathrm{z}$ zachodnimi i północnymi sąsiadami w dużym stopniu udoskonalono oznakowanie granic, na znaki graniczne wybierając zamieszkałe już pogranicza, rozległe krańce zamieszkałych pogranicznych gmin.

Zagadnienia graniczne z Państwem Moskiewskim nie zostały natomiast rozwiązane, dlatego nie można w tym okresie mówić o odnawianiu i korygowaniu granic, a także o udoskonalaniu ich oznakowania. Rywalizacja terytorialna miała tam znaczny wpływ na rozwój kolonizacji wewnętrznej i nie pozwoliła na wykształcenie się linii granicznej. Porozumienia na pograniczach miały charakter lokalny, nie przyjęto żadnych konkretnych rozwiązań, które zapewniłyby bezpieczeństwo na pograniczach, warunkujące kolonizację wewnętrzną.

Ważnym elementem wskazującym na regionalną specyfikę rozwoju litewskich granic są traktaty zawarte wyłącznie w kwestiach granicznych. Z Inflantami pierwszą taką umowę zawarto w $1473 \mathrm{r}$. To pierwsza umowa międzynarodowa poświęcona wyłącznie kwestiom delimitacji, nie umieszczono w niej żadnych innych ustaleń. W tym czasie z Państwem Moskiewskim i południowymi sąsiadami nie zawierano umów poświęconych wyłącznie zagadnieniom granicznym.

Rozważania o przejściu między Grenzsaum a Grenzraum zawierają już prace Karpa z początku lat 70. XX w. Kwestia nowego (i jeszcze nowszego) podejścia do zagadnienia mogłaby zostać przedstawiona bardziej klarownie.

\section{Streszczenie}

Celem niniejszego artykułu jest analiza regionalnej specyfiki i przemian granic oraz terenów przygranicznych Litwy i jej sąsiadów w XV i XVI stuleciu. Zaprezentowane zostały i omówione poszczególne fazy rozwoju litewskich granic państwowych. Kraje sąsiadujące z Wielkim Księstwem Litewskim - Polska, Moskwa, zakon kawalerów mieczowych i zakon krzyżacki, Mołdawia, ordy tatarskie oraz, w późniejszym okresie, Imperium Osmańskie - tworzyły i oferowały rozmaite modele sąsiedztwa pod względem podejścia do lokalnej kultury. Pojęcie granic państwowych zależne było bezpośrednio od rodzaju sąsiedztwa $\mathrm{z}$ danym państwem oraz modelu granicy wypracowanego $\mathrm{w}$ ramach wzajemnych międzypaństwowych relacji. To samo państwo mogło z powodzeniem $\mathrm{w}$ jednym czasie mieć odmienne granice w różnych obszarach pogranicznych: zarówno linearne, jak i nielinearne, a także strefowe. Linearne granice państwowe wieńczyły długotrwały proces militarnego, społeczno- 
-gospodarczego i kulturowo-ideologicznego podboju terytorium. Model ten odnosił się jedynie do północnej i zachodniej granicy państwa litewskiego. Najważniejszym warunkiem wstępnym tworzenia się granicy liniowej jest wewnętrzna kolonizacja. Linia podziału pomiędzy dwoma krajami może przekształcić się w linię oddzielającą terytorium państwa od obszaru zewnętrznego jedynie w wypadku istnienia odpowiedniej bazy społecznej i gospodarczej. W pierwszej połowie XVI stulecia dotyczyło to jedynie zachodnich i północnych rubieży Wielkiego Księstwa Litewskiego, natomiast zupełnie inne były warunki na pograniczu wschodnim i południowym. Kwestia granic nie została rozwiązana z państwem moskiewskim ani z południowymi sąsiadami; na pograniczu południowym zasadnicze znaczenie dla kolonizacji wewnętrznej miały naturalne warunki geograficzne, dlatego generalnie nie jest możliwe omawianie zmian tej granicy w analizowanym okresie.

\section{The Regional Specificity of the Concept of Borders and Borderlands of the Grand Duchy of Lithuania in the Fifteenth and Sixteenth Centuries Summary}

The aim of this article is to present the concept and specificity of the borders and borderlands of Lithuania and its neighbours in the fifteenth and sixteenth centuries. The development phases of the Lithuanian state borders are presented and discussed in the context of the theory of border development. The states which bordered on the Grand Duchy of Lithuania: Poland, Muscovy, Livonian and German Order, Moldavia, Tatar hordes and - in the later period - the Ottoman Empire, offered different models of neighbourhood in terms of the regional cultural approach. The concept of state borders depended directly on the type of neighbourhood with another political entity and the border model was shaped by inter-state relations. The same state could have different border types with different border areas at the same time: both linear and non-linear or zonal ones. Linear state borders were finally formed after a military, socio-economic and cultural-ideological conquest of the area. The linear border model is applicable only to the northern and western borders of Lithuania. An internal colonization is regarded as the most important precondition for the creation of a linear border. Only as a result of a sufficient social and economic basis could the line dividing the states turn into a line which restricts the state area from the inside and from the outside. In the first half of the sixteenth century such a situation had already been established on the western and northern borderlands of the Grand Duchy of Lithuania. The border question was not resolved with Muscovy and the southern neighbours; natural circumstances had a significant impact on the internal colonization of the southern borderlands, this is why it is not possible to discuss changes of the borders during this period.

\section{Bibliografia}

\section{Źródła drukowane}

Acta Alexandri Regis Poloniae, Magni Ducis Lithuaniae etc. (1501-1506), wyd. F. Papée, Kraków 1927 (Monumenta Medii Aevi Historica Res Gestas Poloniae Illustrantia, t. 19).

Acta Tomiciana, t. 1: 1507-1511, Posnaniae 1852; t. 2: 1512-1513, Posnaniae 1852; t. 5: 1519-1521,

Posnaniae 1855; t. 6: 1522-1523, Posnaniae 1857; t. 10: 1528, Posnaniae 1899; t. 11: 1529, Posnaniae 1901.

Codex diplomaticus Regni Poloniae, t. 1, 4, 5, wyd. M. Dogiel, Vilnae 1758, 1764, 1759.

Codex epistolaris Vitoldi magni ducis Lithuaniae 1376-1430, wyd. A. Prochaska, Cracoviae 1882. 
Dokumenty strony polsko-litewskiej pokoju metneńskiego z 1422 roku, wyd. P. Nowak, P. Pokora, Poznań 2004.

Kodex dyplomatyczny Litwy, wyd. E. Raczyński, Wrocław 1845.

Kodeks dyplomatyczny księstwa Mazowieckiego, obejmujący bulle papieżów, przywileje królów polskich $i$ książąt mazowieckich, tudzież nadania tak korporacyj jako i osób prywatnych, wyd. J.T. Lubomirski, Warszawa 1863.

Lietuvos Metrika. Knyga Nr. 5: 1427-1506; Užrašymų knyga 5, wyd. E. Banionis, Vilnius 1993.

Lietuvos Metrika (1540-1543); 12-oji Teismų bylu knyga (XVI a. pabaigos kopija), wyd. I. Valikonyte, N. Šlimienè, S. Viskantaitė-Saviščevienè, L. Steponavičienè, Vilnius 2007.

Liv-, esth- und curländisches Urkundenbuch nebst Regesten, t. 5: 1414-1423, wyd. F.G. von Bunge, Riga 1867.

Lites ac res gestae inter Polonos ordinemque Cruciferorum. Comprehendit causam actam anno 1412, additamentum, t. 2, Posnaniae 1892.

Limites Regni Poloniae et Magni Ducatus Lituaniae, wyd. M. Dogiel, Vilnae 1758.

Skarbiec diplomatów papiezkich, cesarskich, krolewskich, książęcych; uchwat narodowych, postanowień różnych władz i urzędów posługujących do krytycznego wyjaśnienia dziejów Litwy, Rusi Litewskiéj i ościennych im krajów, t. 1-2, oprac. I. Daniłowicz, Wilno 1860-1862.

Die Staatsverträge des Deutschen Ordens in Preussen im 15. Jahrhundert, t. 1: 1398-1437, wyd. E. Weise, Königsberg 1939.

Акты, относящиеся к истории Западной России, t. 1-2, Санкт Петербург 1846.

Археограбический сборник документов, относящихся к истории Северозападной Руси, t. 1, Вильна 1867.

Духовныя и договорныя грамоты великихъ и удюльныхъ князей XIV-XVI вв., Москва 1950.

Книга Посольская Метрики Великого княжества Литовского, содержащая в себе дипломатические снотения Литвы в государствование короля Сигизмунда Августа (с 1545 по 1572 год), wyd. М. Оболенский, И. Данилович, Москва 1843.

Метрыка Вялікага Княства Літоўскага (1542). Кніга № 560. Книга перепісаў № 3 (Копія каниа XVI cm.), Мінск 2007.

„Сборник Императорскаго Русскаго Историческаго Общества” (СбРИО)

Тетрадь, а в ней писаны рубежи городу Полоику и Полоикому повету 7071 (1563) года, „Временник Императорского Московского общества истории и древностей российских” 24, 1856, nr 2, s. 1-48.

\section{Opracowania}

Arnold B., Princes and Territories in Medieval Germany, Cambridge 1991.

Berend N., Medievalists and the Notion of the Frontier, "The Medieval History Journal” 2, 1999, nr 55, s. 55-72.

Bucevičiūtė L., Lietuvos Didžioji Kunigaikštystė XV-XVI a. Valstybès erdvės ir jos sienu samprata. Mokslo monografija, Kaunas-Vilnius 2015.

Bucevičiūtė L., Lietuvos valstybès teritoriniai kontaktai rytuose XV-XVI a. Keletas sienu istorijos epizodu, „Istorija” 78, 2010, nr 2, s. 3-14.

Bucevičiūtè L., Stepès teritorine specifika XVII-XVIII a. Geografinis ir kartografinis aspektas, „Darbai ir dienos" 61, 2014, s. 213-232.

Bucevičiūtè, L., Valstybès erdvès samprata Lietuvos Didžiosios Kunigaikštystès teisés dokumentuose (XV-XVI a.), „Lietuvos istorijos metraštis” 1, 2009 [2010], s. 51-68.

Čelkis T., Lietuvos Didžiosios Kunigaikštystés sienu stepèse XIV-XVI amžiuje samprata, „Lietuvos istorijos studijos" 30, 2012, s. 29-35. 
Čelkis T., Lietuvos Didžiosios Kunigaikštystès sienu sutartys ir delimitacijos procedūra XIV-XVI amžiuje, „Lietuvos istorijos studijos” 25, 2010, s. 25-47.

Čelkis T., Lietuvos Didžiosios Kunigaikštystès teritorija. Sienų samprata ir delimitaciniai procesai XIV-XVI amžiuje, Vilnius 2014.

Čelkis T., Lietuvos Didžiosios Kunigaikštystès teritorijos sienos „prie Juodosios jūros” XV-XVI a., „Istorija” 83, 2011, s. 3-13.

Čelkis T., Nuo teritorinio ruožo prie linijos. Sienu sampratos pokyčiai Lietuvos Didžiojoje Kunigaikštystèje XIV-XVI amžiuje, „Lietuvos istorijos studijos” 22, 2008, s. 58-73.

Čelkis T., Valdžia ir erdvé. Lietuvos Didžiosios Kunigaikštystès teritorializacijos procesas XIV-XVI a. Disertacija, Vilnius 2011.

Čelkis T., Žemiu ribų ženklinimas Lietuvos Didžiojoje Kunigaikštystëje XV-XVI amžiuje, „Liaudies kultūra" 2013, nr 4, s. 16-26.

Čelkis T., Antanavičius D., 1545 metų Livonijos ir Lietuvos Didžiosios Kunigaikštystès sienos patikrinimas (Livonijos pareigūnu ataskaita), „Lietuvos istorijos studijos” 27, 2011, s. 164-178.

Długokęcki W., Kowalczyk E., Nieznane opisy granicy mazowiecko-krzyżackiej, cz. I: Granice komornictwa działdowskiego i nidzickiego, „Kwartalnik Historyczny” 110, 2003, nr 1, s. 29-50.

Długokęcki W., Kowalczyk E., Nieznane opisy granicy mazowiecko-krzyżackiej, cz. II: Granica komturstwa bałgijskiego (prokuratorstwo piskie i ełckie), „Kwartalnik Historyczny” 2004, 111, nr 1, s. 5-37.

Długokęcki W., Kowalczyk E., Opis granicy Mazowsza z państwem zakonu krzyżackiego, „Kwartalnik Historyczny" 109, 2002, nr 2, s. 5-14.

Dorna M., Akt delimitacji litewsko-inflanckiej z 7 lipca 1473 roku, „Lituano-Slavica Posnaniensia. Studia Historica" 14, 2013, s. 87-102.

Dziubiński A., Polsko-litewskie napady na tureckie pogranicze czarnomorskie w epoce dwu ostatnich Jagiellonów, „Kwartalnik Historyczny” 103, 1996, nr 3, s. 53-86.

Dziubiński A., Stosunki dyplomatyczne polsko-tureckie w latach 1500-1572 w kontekście międzynarodowym, Wrocław 2005.

Elden S., Land, Terrain, Territory, „Progress in Human Geography” 34, 2010, nr 6, s. 804-812.

Etulain R.W., Meeting Places, Intersections, Crossroads, and Borders. Toward a Complex Western Cultural History, „The Historian” 2004, 66, nr 3, s. 509-516.

Forstreuter K., Die Entwicklung der Grenze zwischen Preußen und Litauen seit 1422, „Altpreußische Forschungen" 18, 1941, nr 1, s. 50-70.

Ivinskis Z., Kovos bruožai dèl Žemaičiu ir jų sienų, „Athenaeum” 6, 1936, s. 54-117.

Ivinskis Z., Lietuvos istorija. Iki Vytauto Didžiojo mirties, Vilnius 1991.

Ivinskis Z., Lietuvos valstybingumo išplètimas slavų erdveje, „Tautos praeitis” 1, 1962, nr 4, s. 501-502.

Jack S.M., The 'Debatable Lands', terra nullius, and Natural Law in the Sixteenth Century, „Northern History" 41, 2004, nr 2, s. 289-290.

Jakubowski J., Przykład zmienności granic administracyjnych na Litwie w w. XVI, „Ateneum Wileńskie" 10, 1935, s. 161-164.

Jones R., Categories, Borders and Boundaries, „Progress in Human Geography” 33, 2009, nr 2, s. $185-186$.

Jones R., The Spatiality of Boundaries, „Progress in Human Geography” 34, 2010, nr 2, s. 263-267.

Karp H.J., Grenzen in Ostmitteleuropa während des Mittelalters, Köln 1972.

Kowalczyk E., Rajgród 1360 r. Przyczynek do dziejów granicy mazowiecko-krzyżackiej, „Kwartalnik Historyczny" 113, 2006, nr 3, s. 5-18.

Kristof L.D., The Nature of Frontiers and Boundaries, „Annals of the Association of the American Geographers" 49,1959, nr 3, s. 269-282.

Łowmiański H., Studia nad dziejami Wielkiego Księstwa Litewskiego, Poznań 1983. 
Małłek J., Granice państwowe, kościelne i administracyjne Prus Książęcych w XVI w., „Komunikaty Mazursko-Warmińskie" 1966, nr 1, s. 131-139.

Maroszek J., Pogranicze Litwy i Korony w planach króla Zygmunta Augusta: z historii dziejów realizacji myśli monarszej między Niemnem a Narwia, Białystok 2000.

Michaluk D., Памежныя спрэчки памиж Каронай і Вялікім Княствам Літоўскім у 16-17 cmcm. На прыкладзе Мельницкай и Берасцейскай земляў, „Гістарычны альманах” 5, 2001, s. 23-53.

Michaluk D., Ziemia mielnicka województwa podlaskiego w XVI-XVII wieku. Osadnictwo, własność ziemska i podziały kościelne, Toruń 2002.

Natanson-Leski J., Dzieje granicy wschodniej Rzeczypospolitej. Granica moskiewska w epoce Jagiellońskiej, cz. 1, Lwów-Warszawa 1922.

Natanson-Leski J., Epoka Stefana Batorego w dziejach granicy wschodniej Rzeczypospolitej, Warszawa 1930.

Novak P., The Flexible Territoriality of Borders, „Geopolitics” 2011, nr 16, s. 741-767.

Pociecha W., Królowa Bona (1494-1557). Czasy i ludzie odrodzenia, t. 3, Poznań 1958.

Schubert E., Fürstliche Herrschaft und Territorium im späten Mittelalter, München 2006.

Schubert E., Der Rätselhafte Begriff „Land” im späten Mittelalter und in der frühen Neuzeit, „Concilium Medii Aevi" 1998, s. 15-27.

Spuler B., Mittelalterliche Grenzen in Osteuropa. I. Die Grenze des Großfürstentums Litauen im Südosten gegen Türken und Tataren, „Jahrbücher für Geschichte Osteuropas” 1941, z. 2/4, s. $152-170$.

Szweda A., Methoden der Schlichtung von Grenzstreitigkeiten zwischen Polen-Litauen und dem Deutschen Orden nach Abschluss des Friedens von Brześć im Jahre 1435. Am Beispiel des in Toruń und Nieszawa wirkenden Grenzgerichts, w: Grenze und Grenzüberschreitung im Mittelalter. 11. Symposium des Mediävistenverbandes vom 14. bis 17. März 2005 in Frankfurt an der Oder, Berlin 2007 , s. 54-65.

Szweda A., Tryb i metody przeprowadzania delimitacji między Królestwem Polskim a państwem zakonu krzyżackiego w Prusach w XIV i XV wieku, w: Pogranicza: przestrzeń kulturowa, Olsztyn 2007, s. 15-26.

Šabuldo F., „Semiono žmonès”. Ju teritorija ir vaidmuo Krymo ir Lietuvos politiniuose santykiuose $X V$ a. pabaigoje, „Lietuvos istorijos metraštis” 1, 2010 [2011], s. 5-21.

Varakauskas R., Lietuvos ir Livonijos santykiai XIII-XVI a., Vilnius 1982.

Varakauskas R., Lietuvos ir Livonijos santykiu po Pabaisko mūšio klausimu, „Lietuvos TSR aukštụjų mokyklų mokslo darbai. Istorija" 14, 1974, s. 45-59.

Wenskus R., Das Ordensland Preussen als Territorialstaat des 14. Jahrhunderts, w: Ausgewählte Aufsätze zum frühen und preußischen Mittelalter, red. H. Patze, Sigmaringen 1986, s. 347-382.

Wilkiewicz-Wawrzyńczykowa A., Spory graniczne polsko-litewskie w XV-XVII w., Wilno 1938.

Wojtkowiak Z., Delimitacja litewsko-kurlandzka z 1584 roku, „Lituano-Slavica Posnaniensia Studia Historica" 3, 1989, s. 270-276.

Wojtkowiak Z., Dryświaty - rubież litewska w średniowieczu, „Lituano-Slavica Posnaniensia. Studia Historica" 1, 1985, s. 115-139.

Wojtkowiak Z., Lithuania Transwilniensis saec. XIV-XVI. Podziały Litwy północnej w późnym średniowieczu, Poznań 2005.

Wojtkowiak Z., Pótnocna granica Litwy w średniowieczu. „Limites inter Litvaniam et Livonia” z 1473, w: Poznań - Wilnu. Studia historyków w roku tysiąclecia Państwa Litewskiego, red. Z. Wojtkowiak, Poznań 2010, s. 213-270.

Żdan M., Stosunki litewsko-tatarskie za czasów Witołda, w. ks. Litwy, „Ateneum Wileńskie” 7, 1930, nr 3-4, s. 529-601.

Грушевський М., Історія України-Руси, t. 4, Киів-Львів 1907. 
Грушевський М., Южнорусскіе господарскіе замки въ половине XVI века, „Историко-статистическій очеркъ. Университетския известія" 30, 1890, nr 2, s. 1-33.

Петрунь Ф., Нове про татарську старовину Бозько-Дністрянського степу, „Східний світ” 1928 , nr 6, s. 162-263.

Петрунь Ф., Східня межа Великого Князівства Литовского в 30-х роках XV сторіччя, w: 36ірник Історично-філологічного відділу УАН. Ювілейний збірник на потану акад. М.С. Грушевського, Київ 1928, s. 165-168.

Петрунь Ф., Ханські ярлики на українські землі (До питання про татарську Україну), „Східний світ" 1928, nr 2, s. 170-185.

Темушев В.Н., „Вайна пад час міру”. Першая памежная вайна ВКЛ з Масквою (1486-1494), „Беларускі Гістарычны Агляд” 15, 2008, s. 5-48.

Темушев В.Н., Гомельская земля в конце XV - первой половине XVI в. Территориальные трансформачии в пограничном регионе, Квадрига 2009.

Темушев В.Н., На ўсходняй мяжы Вялікага Княства Літоўскага (сярэдзіна XIV - першая палова XVI cm.), Смаленск 2014.

Темушев В.Н., Река Угра - вековой страж московско-литовской границы, w: Новая токальная история. Пограничные реки и культура берегов. Материаль второй Международной Интернет-конференции. Ставрополь, 20 мая 2004 г., Ставрополь 2004, s. 305-317.

Темушев В.Н., Феномен московско-литовского порубежья XV в., w: Вялікае княства Літоўскае i яго суседзі у XIV-XV стст. Саперніцтва, супрацоўніцтва, урокі: да 600-годдзя Грунвальдскай бітвы: матэрыялы Міжнар. навук. канб. (Гродна, 8-9 ліп. 2010 г.), Мінск 2011, s. 199-206.

Темушев В.Н., Формирование московско-литовской границы в XV - начале XVI в., „Studia Historica Europae Orientalis. Исследования по истории Восточной Европы, Научный сборник" 1, 2008, s. 56-76.

Темушев В.Н., К вопросу о московско-литовской границе XV в. (владения князей Крочинских), „Древняя Русь. Вопросы медиевистики” 2005, nr 3(21), s. 102-103.

Темушев В.Н., К вопросу о московско-литовской границе XV в. (владения князей Крочинских), „Ruthenica” 2007, nr 6, s. 299-307.

Темушев В.Н., Сведения о московско-литовском пограничье в посольских книгах времени Ивана III, w: Труды кафедры истории России с древнейших времен до ХХ века, Санкт Петербург 2006, s. 294-306.

Шабульдо Ф.М., „Семеновы люди”. Их территория и роль в политических отночениях между Крымом и Литвой на исходе XV века, „Ruthenica” 2010, nr 9, s. 57-73.

Шабульдо Ф.М., Земли Юго-Западной Руси в составе Великого княжества Литовского, Киев 1987.

Laima Bucevičiūtè - doktor; wykładowca Uniwersytetu Witolda Wielkiego w Kownie. Zainteresowania badawcze: pojęcie przestrzeni oraz dzieje terytorium i granic Wielkiego Księstwa Litewskiego. E-mail: laima.buceviciute@vdu.lt 